\title{
Temple Reform and Economic Policy of Religion in Republic of China
}

\author{
Yongkang Wang ${ }^{1, a}$ \\ ${ }^{1}$ Institute of Taoism and Religious Cultures, \\ Sichuan University, Chengdu, Sichuan Province, China \\ a245275768@qq.com
}

Keywords: Policy of religion; Republic of China; Taoism; Temple economic

\begin{abstract}
This paper analyzes the overall situation of religion in the Republic of China, and mainly takes Taoism as an example to analyze and summarize the situation and adjustment of religion in the aspects of "miaochan xingxue (build schools with temple property)", "dispelling superstition", "operating schools" and "charity enterprises". The study of traditional religion in the Republic of China is an important subject in the modern study of religion. This paper uses various historical materials to investigate the overall living environment (political environment, economic environment, humanistic environment, religious policy, temple reform) and the development of Taoism in the Republic of China, as well as the historical development circles of Taoist institutions (Taoist association, Taoist educational institution, etc.), the relationship between government dignitaries, local warlords and Taoists, and the charity of Taoism.
\end{abstract}

\section{Introduction}

After the revolution of 1911, the autocratic monarchy was denied, and Chinese history gradually conformed to the trend of the world democracy. In the following less than 40 years, it was one of the most dramatic social transformations in the history of China. On the one hand, after the autocratic monarchy of more than two thousand years was ended, China changed rapidly from a feudal society to a modern one. The disintegration of the traditional national system caused political and economic fragmentations, various contradictions, internal and external problems, and social unrests. On the other hand, the influx of western culture greatly influenced the thinking mode of the scholars at that time and broadened their horizons, which made the academic of the Republic of China shine brilliantly. For its own reasons and the restrictions of the external policy environment, the decline of traditional Chinese religions continued since the late Qing dynasty. At the same time, in the face of the reform, the traditional religion itself had made some adjustment.

\section{The General Environment of the Republic of China}

At the end of the 19th century and early 20th century, the Qing dynasty had become a teetering country, with economic bankruptcy, military weakness, international status declining and the threat of the dangerous predators, such as Japan in 1895 and main western powers in 1900. These two war disasters, causing an ideological crisis in this country, led to the denial of thousands of years of traditional culture. Although the empire survived until 1911, attempts at radical fragmentation of the state and the creation of modern Nations began in 1898. Building a nation state means the destruction and reconstruction of society as a whole, including religion. In fact, the destruction of the religion of the old regime and the creation of a new religious place in the nation state are an important part of the modernization of China from the Qing (Ching) dynasty to the Republic of China.

The first radical religious reform began in 1896, with Zhang Zhidong as the representative of local power of the late Qing dynasty, initiated the "miaochan xingxue" reform. This reform, though only last a short period, but when it was combined with the westernization movement in the late Qing dynasty, introducing and popularizing the idea of nationalizing the temple, and using the temple property to build schools or other infrastructure. Then, the role of religion and superstition in the establishment of modern countries was further denied, and these ideas were extended to national 
execution.

\section{Period of Nanjing Provisional Government (1912)}

On January 1, 1912, the Provisional Government of Nanjing was proclaimed, when Sun Yat-sen took office as the temporary president. To the end of the mainland Kuomintang (KMT) regime in 1949, this period is known as the Republic of China, for a total of 38 years. The period from January to early April 1912, was known as the period of Nanjing Provisional Government of the Republic of China. Though the Nanjing Provisional Government was short and lasted for only three months, its influence in the history of the Republic of China has been profound and significant.

From Kristofer Sshipper's study, when Sun Yat-sen studied in Honolulu as a young man, he began to believe in Christianity and joined the church then. According to survey records of Japanese, Sun Yat-sen often attacked Confucianism and Taoism, one can imagine he took a very strict attitude to Chinese traditional religions. The Provisional Constitution enacted at the beginning of the Republic of China in 1912 exerted a great influence on Confucianism, Buddhism and Taoism. Article 2 of the document stated that "the sovereignty of the Republic of China shall be vested in the whole of the nation", and article 5, "equal to people of the Republic of China, and no distinction between the religious differences of racial classes", and article 6, "The people have the freedom of belief"' 1$]$.

\section{Period of Beiyang Government (1912-1927)}

In April 1912, Yuan Shikai moved the Provisional Government from Nanjing to Beijing, and until 1927 this period was known as the ruling period of the northern warlords in Chinese history --“Beiyang Government period".

In this period, in order to strengthen the Taoist forces, Chen Minglin and other Taoist leaders initiated the establishment of the society, to unite the national Taoist force, with a momentum to strive for survival. Thus, in July 1912, the first national Taoist association, the "Central Taoist Association", was established since the beginning of the Republic of China, with its headquarters in Beijing Baiyunguan temple. But the "Central Taoist Association" did not have a national appeal. In the same year, Zhang Yuanxu went to Shanghai, followed by the establishment of "Shanghai general deputy of Jiangxi headquarters of Taoism of the Republic of China ".

In 1913, a representative of Zhengyi Taoism, headed by Zhang Yuanxu, held a meeting of the founders of "the Taoist Association of the Republic of China" in Shanghai, drafted the proposal book, put forward the purpose of "flourishing Taoism, succeeding to the morals", and proposed to establish schools, hospitals, industries and commerce, etc., which were not realized without the approval of the government.

In June 1913, the Beiyang Government announced the provisional rules for the management of monasteries, which stipulated that, "the management of temple property shall be held by its abbot; no person shall forcibly take away the property of the monastery; the abbot of the monastery and other relations shall not sell, mortgage or grant the property of the monastery, but the special case may be refused by the permit of the chief executive of the province." This was a landmark document. According to the articles of the document, the temple had lost its right to freely dispose of the temple itself since then.

In August 1913, the Ministry of the Interior issued a ban on witchcraft. In order to forbid all temples to sign and sell divination and be engaged in fortune-telling and other superstitious behavior. However, Taoism was the religion of Chinese native soil, it had a long history of communication and was combined with philosophy Taoism in theory and mixed with folk beliefs, so it could be widely spread and become the social foundation of Taoism. The attack caused by this order actually broke the foundation of the life of many regular and folk Taoist priests.

In September 1913, the Government Ministry of the Interior, in a written form, indicated that it had no ability to trace the previously occupied temples. It should be noted that the Ministry of the Interior had responded in writing to the previously forced looting and possession of the temple. All this was directly related to the "Provisional constitution", which brought a large number of violence to disrupt 
the temple incidents to the temple. In October, the national temple property survey was organized. In this investigation, only the temple property was obliged to be registered, but not to be protected, such subtle behavior was profound.

In 1914, the 62nd generation of the Heavenly Master (Zhengyi Tianshi) of Tianshi Tao Zhang Yuanxu, who curried favor with Zhang Xun, the Yangtze river xunyueshi, Zhang Xun preferred the Taoist rituals and sent personnel to the Longhu Mount to meet Zhang Yuanxu at the military palace. In the same year, Zhang Xun recommended Zhang Yuanxu to the capital for half a month, and performed three framework of the Retreat (zhai ) and Offering (jiao) services in Xinhua Palacein Beijing. Yuan Shikai then restored the Title of the Heavenly Master, restored the property, issued a new Zhengyi Master seal, and gave "Sandeng jiahe" medals and a "Daoqi kongtong" horizontal tablets. Then the fate of the Longhu Mount began to change better. Yuan Shikai himself wanted to win over the social circles, including religious leaders, and formulated policies to protect the traditional sacrifice rituals of local traditional religion. Since then, the good luck of Taoism industry continued until the end of Yuan Shikai regime in 1916.

The 20th century was the "Warlord Era" in the history of China, generally believed to have its beginning upon the death of Yuan Shikai in 1916. The failure of Yuan's reconstruction of the empire was a convenient door for the warlords and the local separatism. Yuan's death showed that there was no one powerful figure in China who could maintain the centralized rule after the collapse of the Qing dynasty. The political pattern of this kind of warlord also laid the mark of the times for this stage of Taoism. Take Sichuan Qingcheng Mount as an example, "during the warlords-ruling period, in order to defend the property from being confiscated and robbed", Taoist abbot Peng Chunxian went to Chengdu to file a lawsuit in person, but he was arrested because he offended the warlord's benefit, finally even the temple abbot himself was forced to go to exile to take refuge.

In October 1918, Xu Shichang was elected president by the new parliament (in office for five years). This was the result of the compromise reached between the Beiyang warlords and Xu himself was the only civilian president during the period of the Beiyang warlords. $\mathrm{Xu}$ once passed the imperial Jinshi examination in his 30s, and awarded the imperial academy editing. $\mathrm{Xu}$ cast his lifelong faith in Taoism, especially in the LV Dongbin. Thus while Xu was elected president, the Taoist community clearly felt the free atmosphere had come. In this year, the Hevenly Master of Longhu Mount was completed the genealogy of the Tianshi to the 61st generation, named "Bu tianshi shijia" ("complement Hevenly Master's aristocratic family").

But the new round of shocks soon came again. On May 4th, 1919, the signing of the "Paris Peace Treaty" detonated the vigorous "May 4th Movement". This movement, known as the turning point from the old Chinese democratic revolution to the new-democratic revolution, began with the opposition to imperialism, and soon a comprehensive impact on the ancient Chinese cultural traditions ensued. Old religions and old customs, including Taoism, all were among the critical targets. For example, Chen Duxiu believed that the God, celestial, fairy, Buddha were all "deceitful idols". Qian Xuantong thought that it was necessary to exterminate Taoist theology. Hu Shi's criticism of Taoism was the most intense, as he believed the Taoist was "the most superstitious" and he believed "Taoist canon" was a set of false books, "full of amazing superstitions and very little academic value". There is no doubt that the social atmosphere influenced by this kind of cultural elite made the living space of Taoism further squeezed[2].

In 1921, Sik Sik Yuen was created in Hong kong, commonly known as Wong Tai Sin temple. The Wong Tai Sin temple in Hong kong was founded by the Guangdong people Liang Ren'an, and its inheritance of Taoism came from the Puji altar in Fangcun village, Guangzhou. Until the revolution of 1911, Puji Taoism had also expanded the houses because of exuberant incense. In 1913, it was confiscated by the Guangdong police office and used as a kindergarten. Since then, the disciples of Puji altar spread everywhere, some still adhering to the development of the belief in Wong Tai Sin, one of which was Liang Ren'an[3].

As Mr. Sun Yiping has said in Dongya daojiao yanjiu "followers of these faiths have moved from the Pearl River Delta to Hong kong" because of "disaffection with the regime", "the establishment of Taoist temples in Hong kong, such as the Tin Hau temple in Causeway bay, the Wong Tai Sin temple 
and Yunhe shanfang in Kowloon ", “had a influence on the development of Hong kong's Taoism”[4]

In 1923, Chen Minglin, the abbot of Baiyunguan Temple mobilized all of the parties and organized a charity performance to help Quanzhen believers through difficulties, even Baiyunguan Temple, the oldest and most famous temple of Quanzhen Taoism got suffered during the hard times, not to mention other temples.

In October 1923, 13 people, such as Zhang Jian, Kang Youwei, Liang Qichao and Huang Yanpei, launched a project to reprint the Taoist Canon of the Ming dynasty version. The then president, $\mathrm{Xu}$ Shichang, gave his support in money. Using the collection of Beijing Baiyunguang Temple as the master copy, the photocopy from the Shanghai Hanfenlou press was used as a thread-bound, including 1120 volumes, 5,486 scrolls (juan), which were proved invaluable for later studies of Taoist Canon. Started in 1923, the photocopy of Taoist canon of Shanghai Hanfenlou completed and came out in 1926, and then from the selection of more than 100 kinds of scriptures, printed Daozang juyao (Summary of Taoist canon). 350 sets of the new edition of the Taoist Canon were printed, each set consisting of 1120 volumes and priced at 800 silver dollars. The libraries in China Taoism were too poor to buy, so most were sold abroad.

In 1924, Zhang Yuanxu, the 62nd generation of Tianshi (Hevenly Master) of Zhengyi Taoist, died in Shanghai, and his eldest son, Zhang Enpu, inherited the Title of Tianshi, was the 63rd generation of the Zhen gyi Taoist. Later, Zhang Enpu was addicted to opium, which ruined the reputation of Taoism in the community.

In October, 1925, at a meeting of the expanded executive Committee of the central committee of the CCP, the communists put forward the slogan "land belongs to peasants" and began to recognize that "the CCP's demand for peasants should be listed as a platform for a peasant problem, with the ultimate goal of confiscating the fields of the temples of large landlords and warlords". Although the $\mathrm{CCP}$ at that time was small, the influence of this public opinion had a very strong influence. As Mr. Luo Zhitian said, "the years before and after the Northern Expedition can be said to be the most crucial turning point in the modern history of China. Later, the KMT and the CCP, who played the leading role on the Chinese political stage, laid their own political and military foundation during that period"[5].

Therefore, it can be said that from the background of the cooperation between KMT and CCP which began in January of 1924, the slogan of "land belongs to peasants" proposed by the CCP was basically to rally the peasants and lay the foreshadowing for a new round of seizure of the temple land.

In 1927, the KMT \& CCP's co-headquarters of Jiangxi province, together with the party headquarters of Guixi county, sent some people to the Longhu Mount to convene the general assembly to reveal the superstitious activities of the Taoist. They burned down the statues of the altar and collected the five Honda books of the Tianshi's mansion and the silver seals of the past dynasties and the jade seals, swords, and so on from the generation of the Tianshi. The local people also arrested Zhang Enpu and had him sent to Nanchang, imprisoned in Jiangxi province farmers association. In March 29, 1927, the sixth meeting of the Wu county provisional administrative Committee of Jiangsu province decided that Zhang Tianshi had been abolished, and that Taoism could not exist, and the Taoist priests should make a living career, and the industry of Taoist priests should accept trainings of occupation, and the civil affairs bureau, the public welfare bureau and the public welfare bureau shall show the notice and prohibit the selling of Taoist properties privately. After the meeting, the county provisional administrative Committee posted the bulletin on the monastery gate of Xuanmiaoguan Temple. The incident caused an alarm among a vast number of people.

During the period from 1912 to 1927 , when the Beiyang government ruled China, the political pattern failed to achieve unity, resulting in local separatism, tangled warfare among warlords, fragmentation of the country, and many social problems. During this period, there had been three great social movements, the "Anti-Yuan Shikai, protect Provisional Consitution movement", the May 4th Movement and the Northern Expedition. The western countries had been bulling and plundering China. On the surface, the attitude of the Beiyang Government in general toward religion was based on the balance of the relationships between various political forces and various religions, 
from the perspective of government religious policy, basically allowing freedom of religious belief, the separation of regime and religion, separation of education and religion. In fact, the Provisional Constitution of the Republic rejected Taoism as the privilege of state tradition, and deposed Yuan Shikai, who was basically a feudalist. The May 4th Movement attributed all Chinese traditional religions to superstition. These movements, from both public opinion and political practice, put Taoism on the road to further decline. As Prasenjit Duara stated in "Culture, Rights and Country Rural Area of North China 1900 - 1942", the attack on religious organizations during the new deal in the late Qing dynasty was the first sign of breaking religious superstition on a large scale in the Republic of China three times (the beginning of the Republic, the May 4th Movement and the late 1920s )[6].

\section{Period of Nanjing National Government（1927-1949）}

After the northern Expedition, China experienced a period of the political stability, economic recovery and development, cultural prosperity, but the state had not yet been truly unified. Because of the expansion of foreign forces and the spread of western culture in China, the accession of some warlords and consortia, such as Chiang Kai-shek's acceptance of Christianity, the four famous Christian families and the unification of the Christian general, these events had facilitated the special treatment of Christianity and Catholicism in China and the "audience effect" of public opinion.

On April 12, 1927, after the coup d' é tat of Chiang kai-shek, the 63th generation Tianshi Zhang Enpu defected to Chiang and was appointed acting deputy commander of the KMT's 21st legion. During this period, the Tianshi's mansion and Shangqinggong temple at Longhu Mount got also repaired. On April 18, Nanjing national government was established. To make good governance and build a modern China, the government generally adopted the policy of restriction and suppression of feudal superstition, traditional customs and the religions. This not only strengthened ideological control to promote the ideological factors of the slogan "Three Principles of the People" in the country, but also the education circle's positive "miaochan xingxue".

More drastic policies rolled out continually. On September 2, 1928, the Ministry of the Interior issued the regulations, and also announced 4 "registration forms" relevant to temple population, temple property, temple Fawu, etc. Overall, the Year 1928 introduced the most policies than any other year. These policies and regulations stipulated that people who disseminated superstitions should be forced to engage in other legitimate occupations, and strictly prohibited the publication of divination and Geomantic Omen books. Temples and statues were no longer under protection. Since 1928 the destruction of temples and statues happened more or less all over the country.

In May 1928, a national education conference was held in Nanjing. Led by Tai Shuangqiu, a professor of the central university, Xue Dubi, the Minister of the Interior, the participants issued the declaration of the "miaochan xingxue", resolutely advocating the abolition of monks and Taoist priests, confiscating the property of the monastery to be used as the educational fund, converting monasteries into schools. In July, the administrative program promulgated by the Ministry of the Interior, contained in Item 10 a regulation of "temple registration", including "investigation of the temple monks and Taoists" and "investigation and management of church members and their properties". On 25 August, the draft of "Temple Registration Ordinance", prepared by the Ministry of the Interior, and various forms were sent to the national government for review and an official letter to the national government on 30 August expressed the desire for an early submission to the conference of the national government. The national government immediately referred the draft of "Temple Registration Ordinance" to the legislative Council for review and urged it to do so as soon as possible. On 8 August, the central Committee of the KMT sent a letter to all localities requesting the suppression of the use of superstitious activities in temples. On September 2, the Nanjing national government announced the implementation of the "Temple Registration Ordinance". The registration was divided into three parts: population registration, real estate registration and Fawu (religious artifact) registration. The registration of the population was limited to monks and Taoists. At the time of registration, the abbot of the temple and the other monks of the deacons' court should also state his duties. They had to apply for registration any time when there was a change in the number of monks 
or Taoists. The temple's real estate included the temple building itself and its affiliated land and houses; Fawu included all the statues of Buddha and Taoism, musical instruments, ancient books and records, sculptures, paintings and other relics that were important in the history or art of religion. And any change in the quantities of the temple's real estate or Fawu had to be registered. The regulations stipulated that in each county, where the county government was responsible for registration, the county government or the public security bureau must conduct an investigation within three days after receiving the registration application of the temple. If the registration of a temple was found inconsistent with the facts, the applicant should be ordered to correct it. The regulations required that "The minors should not be registered as monks and Taoists", "the monks and Taoists would be asked to cancel the registration while returning to secular life." The ordinance also required that, in the event of a contravention of this ordinance, the person might be compelled to register, otherwise the person might be liable to be fined for 100 yuan or to replace the abbot.

From 1929, various temple management regulations for Confucianism, Buddhism and Taoism continued to be issued. In January, the central government again proclaimed the deprivation of the right to dispose of its own property by the temple. In addition to the policy on temple property, there were policies on the management of religious staff, the policy on the management of religious activities, the integration of religious activities into the control and management of the government, on the one hand, classification of religious activities, on the other hand, to urge religious organizations to set up charitable cause.

There is no doubt that since 1928, Chiang kai-shek's Nanjing National Government had implemented a more radical policy in terms of social and cultural customs and religious aspects. While the lunar calendar was abolished, the new calendar came into use. Feudal gods, temple fairs and superstitions were forbidden so as to promote the ideology of the "Three Principles of the People", to occupy or demolish shrines in order to set up educational undertakings. So these policies and campaigns were in serious conflict with China's traditional religions. Moreover, the excessive activity of the KMT's local party headquarters had aroused a lot of local uprisings. In January 1929, in Huaiyuan county, Anhui province, the overthrow of the city's god brewed uprisings. In the same year, the Suqian local branch of the KMT, Jiangsu province, demolished the Dongyuemiao temple to renovate the lecture hall, and the civil commotion of the local religious forces and the local "Xiaodaohui" association broke out.

In 1929, the Taoist of Sanyuangong Temple, Guangzhou, created Fung ying immortal pavilion in Hong kong ( Fung ying immortal pavilionin belonging to the Quanzhen Taoist sect), offering Lao tze, LV Dongbin and Qiu Chuji. It became a Taoist place for recluse originally, and later became a place for public Taoism. This was another big Taoist temple after Sik Sik Yuen which influenced the future Taoist pattern in Hong kong.

In 1930, professor Tai Shuangqiu and other people published the "miaochan xingxue declaration", based on the central university, setting up "promoting society" everywhere, with the task of destroying and occupying temples. In the same year, the CCP of Jiangxi province in the land revolution in the Soviet area, the Tianshi Taoism forces continued to suffer repression.

On October 23, 1930, Chiang Kai-shek was baptized. Except for the absence of Soong Ching- ling, almost all the members of the Soong family were present and blessed for Chiang Kai-shek. In fact, in order to realize the marriage of the Soong family, Chiang had been influenced by Christianity for several years since he met Soong Meiling until his baptism. He even persisted in daily prayer services. That is, in the years before 1930, Chiang was already a Christian actually. There is no doubt that based on the religious beliefs of the central government of the Republic of China, it was difficult not to tilt the development of religious policy towards individual preferences.

On 12 December, 1935, the national conference on education adopted a resolution on the conversion of the national temple property into education fund, and the seizure of all monasteries for schools. Despite the resistance of the religious community, the Nanjing government had repeatedly promulgated the protection of religious and temple orders, but the "miaochan xingxue" wave were out of control, and traditional religion Buddhism and Taoism were under violent shock. In the same year, Zhang Enpu wrote to the ministry of the interior, requesting the release of the official Seal of 
Taoism, restoring the Title of Tianshi (Heavenly master), but rejected by the Ministry of the Interior.

On 4 January 1936, the "temple registration rules" promulgated by the Ministry of the interior of the national government, with a total of 14 articles. It stated that "This rule is not applicable to the temple of Catholicism, Christianity, Islam and Tibetan Buddhism", clearly stating that it does not apply to temples in other religious or border areas. Other regulations on the supervision of temples also indicate that they are not applicable to temples in Tibet province, Xikang province (a part of Sichuan province now), Mongolia and Qinghai province. It clearly indicated that Chiang Kai-shek's Nanjing regime adopted a different treatment to different religions in the formulation and implementation of religious policies and, unlike traditional Confucianism, Buddhism and Taoism, Catholicism, Christianity, Islam and Tibetan Buddhism were not subject to any specific regulation.

From 1937 to 1945, the main contradiction in Chinese society was the one between the Chinese people and the Japanese aggressors. All social groups must show their attitude and decide their own choices in the face of this major contradiction. The majority of Buddhism, Taoism and Islam adhered to the patriotic anti-Japanese position, and there were also a few of the elements attached to the puppet regime. Christianity also adopted the attitude of resistance against Japan for the reasons of anglo-American background, except for individual churches. During this period, the Chinese religious organizations and people devoted great efforts to the anti-Japanese national salvation movement and to the important work of the religious service in the anti-Japanese war. The Taoist community actively assisted the army to resist Japan and host the refugees.

In 1938, some Taoist sects or local religious sects appeared in Shandong. Some factions had thousands of people, usually working in agriculture, fighting against the Japanese invaders and the Japanese collaborators in wartime, and become an anti-Japanese armed force.

In 1942, some Japanese scholars saw in the north of China "few solemn and respectful Taoist temples", Taiyuan Chunyanggong temple "without Taoist priests, but with many women and children concentrating on spinning cotton, apparently being treated as a handicraft workshop". Jinan Changchunguan temple "is also the place of spinning cotton", the inner temple and the Taoist priest "no Taoist knowledge"; "a part of the house is occupied by the police, in front of the Yuhuang dadi emperor (the Jade Emperor, the Supreme Deity of Taoism) in this hall, the residents are cooking"; In 1920, the religious atmosphere was very strong and there were more than ten Taoist priests now. "Part of the local area was used as primary schools, some places used by the police, and the number of Taoist priests was reduced to nine. The role of Taoist temple virtually was non-existent. The past glory of the old days of Tai' an Daizongfang temple is almost gone, and no visitors to the shrine". He only found that Beijing Baiyunguan temple and Shenyang Taiqinggong temple still maintained a veritable Taoist temple face and style.

At that time, Shenyang Taiqinggong temple was the general temple of Taoism in northeast China, Baiyunguan temple is the headquarter of the national Taoist association. There were 78 Taoist priests in Baiyunguan temple, and only a dozen of them literate. The daily work was to clean and labor. As for the provisions on the reading of the classics in the morning and evening, very few Taoists sway around and sun the sun. The Taoists were poor with meager food and patched robes.

If the Taoist priests of Baiyunguan temple had such professional quality, one can imagine how low a level other Taoism temples had. It can be said that Taoism in the great changes of the social revolution in the Republic of China has experienced an unprecedented crisis of survival. While political change was an important reason, the stagnation of Taoism theory and the old way of activity were also inherent factors that cannot be ignored. In a word, throughout the Republic of China, Taoism as a whole decline with fewer and fewer high-level Taoists and leaders.

\section{The Influence and Result}

Since the establishment of the Republic of China in 1912, the country was actually divided most of the time. Even in the days when Yuan Shikai was alive, he could only rely on his clique, and maintain difficultly to form a powerful central government. After Yuan Shikai died, the country disintegrated, until the Northern Expedition of Chiang kai-shek in 1927. During the period of the Chiang kai-shek regime, the CCP party, the local warlords and the Japanese puppet government coexisted during 
different periods and in different regions. After 1927, and to a somewhat lesser but still important extent under KMT regime, the actual unfolding of modern religious policies was characterized by extreme geographic diversity. In order to maintain survival and development, the Taoist or the Buddhism community, in addition to providing the necessary religious services for believers, also did all they could to satisfy the government, set up various types of public welfare and charity, serving the society, operating schools, providing free medical care.

As a result of many factors, compared to the development of environmental freedom, the protection of the various forces of Catholicism, Christianity, Islam and Tibetan Buddhism, Taoism in the period of the Republic of China was controlled and suppressed by various forces. Throughout the Republic of China, the complex social and political situations and the Taoist problems intertwined, leading to the decline of Taoism. The temples were occupied or destroyed, with nuns and laymen scattered. During the Guangxu period of the Qing dynasty, the older generation said that there were only about 80, 000 people all over the country, and later, less and less; In the few years before liberation, they estimated that the number of Taoists in the country was only five tenths of that of Guangxu period of the Qing dynasty. According to local view, "there were 4177 of Taoist nuns left in Sichuan province in 1949, according to the report of Sichuan province in 5th years (1916) of the Republic of China. There were 35,657 Taoists in 145 counties in Sichuan. The comparison between the two figures showed that during the 30 years, the number was reduced by more than $85 \%$ "[7].

Here is the table showing the drastic change in Sichuan province during this period:

Table 1 Taoist data of Sichuan province during the year 1916-1964

\begin{tabular}{|c|c|c|}
\hline Year & Numbers of temple & Numbers of nuns \\
\hline 1916 & - & 35856 \\
\hline 1949 & 787 & 4177 \\
\hline 1964 & 79 & 1307 \\
\hline
\end{tabular}

As can be seen from the table, the number of Taoist temples and Taoist priests decreased sharply during the period of the Republic of China.

\section{Reference}

[1] Provisional Constitution of the Republic of China, Shanghai: Commercial Press, 1916, p.1-2.

[2] Xiao Wanyuan, Chinese modern thinkers' Viewpoint on religion and celestial, Hefei: Anhui people press, 1991, p.349.

[3] Zhong Guofa, Taoism in Hongkong, Beiing: religious culture press, 2010, p.181.

[4] Sun Yiping, Study on Taoism of Eastern Asia, Beiing: people press, 2014, p.156.

[5] Luo Zhitian, Torrent in Troubled Times: Nationalism and politics of Republic of China, Beiing: China Renmin University Press, 2013, p.163.

[6] Prasenjit Duara: culture, rights and country: rural area of north China 1900 - 1942, Nanjing: Jiangsu people press, 2003, p.103.

[7] Tang dachao, Zhongguo daojiao jianshi, Peking: religlious culture press, 2001, p.387. 